DOI: $10.22363 / 2312-8674-2018-17-3-718-734$

\title{
Russian-Egyptian relations in terms of intercivilizational interaction
}

\author{
Galina O. Lukyanova ${ }^{a}$, Elena A. Paymakova ${ }^{a}$ \\ a RUDN University \\ 6 Mikluho-Maklaya St., Moscow, Russia, 117198 \\ lukianova_go@rudn.university
}

\begin{abstract}
The article is devoted to the development of Russian-Egyptian relations in terms of intercivilizational dialogue; there are analyzed the dynamics of their development in various historical epochs as well as the factors that have had decisive influence on the nature of the bilateral interaction. The globalization processes in which the modern world lives are shaking all the models of national and cultural identity that have developed over many centuries. These processes jeopardize the existence of the peoples, nations and cultures in their present form. In these conditions the interethnic cultural dialogue acquires special significance. This article is devoted to the consideration of a similar dialogue between Russian and Egyptian cultures in which political, economic, cultural, scientific and spiritual ties played and continue to play a special role. The ideas of Leo Tolstoy, M. Gorky and other Russian writers got in Egypt a special popularity and had a significant impact on progressive minds of the Egyptian intelligentsia as well as on the Egyptian literature. Although Arab, in particular Egyptian historians and public figures for a long time considered Russia as part of the West, after the October revolution of 1917 in Russia the Soviet state began to be perceived as a force that opposes the materialistic West. From the fifties of the $20^{\text {th }}$ century, the military-technical and economic cooperation with the USSR, subsequently with Russia is of great importance for Egypt. At the same time, the article analyzes the influence of Egyptian culture and art on the spiritual and intellectual life of Russia.

Keywords: Russian-Egyptian relations, intercivilizational interaction, cultures of the East and West, architecture, literature, art, science, education, political situation

For citation: Lukyanova, Galina O., Paymakova, Elena A. "Russian-egyptian relations in terms of intercivilizational interaction." RUDN Journal of Russian History 17, no. 3 (2018): 718-734. DOI: 10.22363/2312-8674-2018-17-3-718-734
\end{abstract}

\section{Introduction}

Despite the considerable distance between Russia and Egypt, great differences in culture and way of life throughout centuries, they have had close relations. It is interaction and certain mutual influence of cultures which are 
the key factors in these relations. Due to the historical reasons, the bilateral cooperation began with the religious sphere, subsequently covering other spheres of the material and spiritual culture. Throughout the history of the development of Russian-Egyptian relations in general, there has been mutual sympathy of the peoples, manifested in a great interest in each other's culture as well as the desire to get acquainted with it. Mutual attraction, rapprochement and enrichment were facilitated by a certain commonality of historical destinies and civilizational mission of the two countries, the geographical position of which made them links between the cultures of the East and the West.

In his book "World after September 11" E.M. Primakov notes: "The uniqueness of Russia's geographical position is that the huge country is a kind of bridge between Europe and Asia. It increases the geopolitical role of Russia, taking into account the difficult process of rapprochement of different civilizations"1. In the book "Egypt and Egyptians" A.M. Vasilyev quotes P. Newbury from his work "Egypt as a field of anthropological research": "Egypt is parchment: the Koran was written on it over the Bible, the Bible over Herodotus, and through all the layers there can be seen ancient Egyptian hieroglyphs"'.

In addition, Russia and Egypt are among the key countries in the system of international relations, acting as poles of influence in the world.

In the context of the restructuring of the system of international relations due to the growing role of Russia in the world, as well as the processes taking place today in the Arab countries, when the region is in the focus of attention not only of specialists, scientists, researchers, but also ordinary people, there is a greater urgency of studying the historical context and prospects for the development of Russia's relations with the Arab countries on the basis of respect for national interests. In this regard, it is the study of Russia's relations with Egypt, one of the key actors in the Arab region, which is of particular importance.

In this paper, the bilateral relations are studied in the aspect of the intercivilizational interaction between the two countries on the basis of various historical sources and scientific literature: documents, archival materials, memoirs and travel notes of Russian scientists and travellers, scientific articles of Russian and Egyptian scholars and researchers.

This work aims to show various aspects of interaction between the two countries in different historical periods, the prerequisites, causes and results of this interaction.

${ }^{1}$ E.M. Primakov, Mir posle 11 sentyabrya (Moscow: Mysl Publ., 2002), 183-184.

2 A.M. Vasilyev, Yegipet i yegiptyane (Moscow: Vostochnaya Literatura Publ., 2008), 225. 
The research methods included the theoretical analysis of the documents on this issue, the study, analysis and synthesis of scientific materials, their systematization and description obtained as a result of the data research.

\section{Spiritual ties between Russia and Egypt in the $14^{\text {th }}-18^{\text {th }}$ centuries}

After the fall of the Byzantine Empire, Moscow positioned itself as the "third Rome", seeing its mission in preserving and protecting the Orthodox faith. Russian pilgrims rushed to the holy places, including those located on the territory of the Egyptian Sinai peninsula. Wishing to render the necessary support to coreligionists, the Russian tsars regularly transferred huge money to the Patriarch of Alexandria and the Archbishop of Sinai. The well-known Russian traveller Alexander Yeliseyev wrote: "From time immemorial, the places of worship of Russian pilgrims have been Mount Athos, Sinai and the holy places of Palestine"3. It is mentioned in the surviving sources that the first pilgrimage of Russians to Sinai took place around 1370 . However, already at that time, the ties between the Russian and Sinai Orthodox churches were quite regular. In 1376, Bishop Mark visited Moscow to receive donations for the monastery of St. Catherine. In 1390, the Sinai monks brought to Moscow a stone with the image of the Burning Bush, which was placed in the Annunciation Cathedral of the Kremlin.

The Russian merchants and pilgrims who had visited Sinai left interesting descriptions of their visits, which at that time were the only source of information about Egypt. They enjoyed great popularity among Russian people. The popularity of these works testified to the considerable interest of enlightened Russians in the holy places located on the territory of Egypt.

Russia traditionally had the closest relations with St. Catherine's Monastery of Mount Sinai, founded in the $6^{\text {th }}$ century under the Byzantine emperor Justinian around the Burning Bush, which is associated with the great popularity of St. Catherine in Russia. Interestingly, the first women's order, established by Peter the Great in 1714, was the Order of Liberation in the name of Great Martyr St. Catherine. The Treasury (Museum) of the monastery has the most valuable icons, among which there are Russian icons.

Under the reign of Peter the Great, in Russia there came a new stage in the study of the countries of the East, which was dictated by the needs of Russia's

${ }^{3}$ V.V. Belyakov, Yegipet vdol i poperyok. Istoritcheskiy gid (Moscow: Vetche Publ., 2005), 264. 
active foreign policy. In 1700, Peter the Great issued a decree on the study of the Oriental languages by Russians, and in Russian educational institutions there was introduced a new discipline - Oriental studies. The study of the East, above all in the Academy of Sciences of St. Petersburg, was dynamically developing under the reign of Catherine II as well, when Russia became the largest empire and a significant force on the world stage, being in the focus of attention of many peoples, including Egyptians. As the Egyptian researcher Mohammad Sabri adDaly notes, there was a mass interest of the Egyptians towards Russia after it dealt the first crushing blow to the Ottoman Empire, at that time Egypt was a part of it; Russia annexed large territories including those inhabited by Muslims and intensified links with the holy places on the territory of Egypt ${ }^{4}$.

As already noted above, it was the Christian community of the Sinai monks which was particularly honoured in Russia: the Russian princes and princesses presented to the monastery a gold lid for the tomb of St. Catherine, two silver reliquaries for her relics, nine cast-iron bells. With the donations of the Russian Orthodox Church, there was built a bell tower of the monastery; in addition, it was granted lands in the Odessa province, the proceeds from which went to its needs. It was the head of the Russian spiritual mission in Jerusalem, the creator of the Imperial Orthodox Palestine Society Archimandrite Antonin (Andrei Ivanovich Kapustin), who worked quite actively. In particular, he was engaged in systematizing the Greek manuscripts stored in the monastery library as well as in compiling their catalogue. In the course of his work he found 38 texts in the Old Slavonic language.

\section{Cultural and scientific relations between Russia and Egypt in the $18^{\text {th }}-19^{\text {th }}$ centuries}

In the first half of the $19^{\text {th }}$ century, under the reign of Egyptian pashareformer Muhammad Ali, who admired Peter the Great and Catherine the Great, Egyptian delegations visited Russia in order to get education and scientific knowledge. N.A. Ivanov notes: "Brought into power by the anti-Mamluk part of the feudal lords, with the support of the large merchant class, Muhammad Ali sought to turn Egypt into a strong centralized state which served the interests of these social classes ... The performing of these tasks required a number of reforms". It was at that time when in Egypt there appeared the first works on the history of Russia. These were the translations of Voltaire's works into Arabic,

${ }^{4}$ Ad-Dali Mohammed Sabri, Contemporary Russia in the Egyptian historical texts (Cairo: Supreme Council for Culture Publ., 2008), 379. 
done on the instructions of Muhammad Ali by Sheikh al-Tantawi, who for many years worked in Russia and subsequently wrote a book about Russia called "Gift to the Smart with Reports on Russia" (1850).

It was during Muhammad Ali's epoch that Russian travellers and orientalists rushed to Egypt, who, according to the Egyptian researcher Ashraf Mohammed Abdel Rahman Munis, "wrote valuable works and books about Egypt, which are considered important historical sources" . For example, A.S. Norov studied in detail the life of the country and the policies of Muhammad Ali. In his book "Journey through Egypt and Nubia in 1834-1835" he described the decisive battle between Muhammad Ali and the Mamluks, noting his deep secrecy, steadfastness and brilliant mind ${ }^{6}$.

At the beginning of the $19^{\text {th }}$ century, in the Russian universities there began the systematic teaching of Oriental languages and Oriental studies: the Oriental languages departments were opened in St. Petersburg, Moscow and Kazan universities. In 1815, in Moscow there was founded the Lazarev Institute of Oriental Languages. In 1854, Nicholas I signed a decree on the opening of the Faculty of Oriental Languages at St. Petersburg University. Prominent Russian orientalists of the 19th century made a great contribution to the establishment and development of the main directions and schools of research in the field of Oriental studies, in particular, Arabic studies (works by O.I. Senkovsky) and Egyptology (V.R. Rozen, V.S. Golenishchev, B.V. Turaev). In 1840, in order to teach the Arabic language at the Foreign Ministry's educational department, there was invited a graduate of Al-Azhar (Egypt), the largest theological university of the Muslim world, the above-mentioned Sheikh Mohammed Ayyad alTantawi, who also worked at St. Petersburg University. In the course of the work, he amassed a magnificent collection of Oriental manuscripts, which are now stored in the library of the Oriental Faculty of St. Petersburg University. From 1846 , he worked as a professor, and subsequently he headed the department of the Arabic language and literature, succeeding O.I. Senkovsky in this post. AlTantawi conducted classed in grammar, translation from Russian into Arabic, Egyptian spoken language, Oriental calligraphy and reading of manuscripts; he lectured on the history of the Arab Caliphate. There are 35 works of alTantawi, the most famous among them being the "Textbook of Conversational Arabic Language" (in French, 1848) and "Gift to the Smart with Reports on Russia" (1850).

5 Ashraf Mohammed Abdel Rahman, Russian Travellers and Orientalists and their Vision of Egypt of the Times of Muhammad Ali (Cairo: Adab Publ., 2015), 99.

${ }^{6}$ A.S. Norov, Puteshestviye po Yegiptu I Nubii v 1834-1835 gg (Sankt-Peterburg, 1840), 98-99. 
The fascination with ancient Egyptian attributes (such as clothing, sculpture, architecture, writing, literature, decor, etc.) in Russia can be considered as one of the manifestations of fashion trends of that time. The phenomenon, called "Egyptology", was a special form of Europe's reaction to the discovery of the treasures of ancient Egyptian civilization. The famous French archaeologist Champollion's deciphering the Rosetta Stone (1822) was a significant event in the history of mankind, which gave rise to the Neo-Egyptian style in art. This style was vividly embodied in the architecture of a number of Mediterranean countries (Spain, Italy, France) as well as St. Petersburg, the capital of the Russian Empire.

In general, Egyptian motives began to manifest themselves in the Russian art long before this discovery. For example, the Pyramid fountain in Peterhof appeared in the era of Peter the Great on the initiative of the emperor himself. Obviously, its shape largely resembles the Versailles fountain "Obelisk". In 1826, in St. Petersburg there was opened the so-called Egyptian bridge, in 1829 in Tsarskoe Selo there was erected the Egyptian gate, decorated with hieroglyphs.

In the $19^{\text {th }}$ century, in Russia there was gradually being established the scientific school of Egyptology; in St. Petersburg there appeared the Egyptian collection of original works, therefore at the Academy of Sciences there was opened the "Egyptian Museum", which was on the first floor of the Kunstkamera.

It should be noted that the active development of the bilateral cooperation was greatly facilitated by the activity of the Russian Steam Navigation and Trading Company, founded in 1856, which had two lines of urgent communication with Egypt, owning the railway, ships, etc. Russian scientists, researchers, experts who travelled to Egypt via the Russian Geographical Society, often wrote memoirs of their travels, which were very popular among the intellectuals of pre-revolutionary Russia. Among the most popular ones were the notes of the Russian physician Alexander Yeliseyev, who was very fond of the East and sensitive to its culture and specifics, "Around the Whole World. Essays and pictures from Dr. A.V. Yeliseyev's travels in three parts of the Old World". They were published in St. Petersburg in 1894-1896 in three volumes with the illustrations of 11 famous artists. The author wrote: "The developed habit of dealing with the orientals, the temptation of objects to be observed and a great deal of interesting material which occurs at every step there - all this began to attract me to the East whenever there was an opportunity and there was extra money in my pocket ..." the Russian intelligentsia representatives for the Egyptians aroused a response: according to A.V. Yeliseyev, during the bombing of Alexandria by the British,

7 O.G. Gerasimov, Vostotchnyye uzory (Moscow: Nauka Publ., 1993), 257-258. 
Egyptians beat Europeans in the streets, seeing them as cruel colonialists, but they left Russians alone. In addition, the attitude towards Russians improved after the Russian-Turkish war of 1977-1978, when hundreds of thousands of captive Muslims saw the cordiality and hospitality of Russians.

All this aroused a great interest in Egypt in the literary and artistic circles of Russia, as evidenced by the appearance of Egyptian motives in the works of Russian classics A.S. Pushkin, M.Yu. Lermontov, F.M. Dostoevsky, L.N. Tolstoy, A.P. Chekhov, I.A. Bunin, a number of architects, sculptors, painters.

Leo Tolstoy took a great interest in the Arab world and Islam, which was largely caused by his education at the Faculty of Oriental Literature at Kazan University, where he tried to learn Arabic. Subsequently, Leo Tolstoy corresponded with the Egyptian imam-educator, innovator, prominent public figure, Egypt's Grand Mufti Muhammad Abdo (1849-1905), and they discussed the issues of morality, ethics, and man's spiritual development. Muhammad Abdo largely shared Leo Tolstoy's philosophical views, recognized his great influence on all progressive, enlightened people of that era. It should be pointed out that Leo Tolstoy was perceived by the Egyptian intelligentsia not only as an outstanding writer and philosopher, but also as a prophet, whose departure from Yasnaya Polyana became a challenge to social injustice and insignificance of the material world. Many of his stories were translated into Arabic already during his lifetime at the turn of the $20^{\text {th }}$ century, but this was an indirect translation from English or French, done by Egyptian émigrés living in England and France. In the 1950s, "Anna Karenina", "Resurrection", "War and Peace" in abridged form were published in Egypt during the educational project "Kitabi" of publisher Helmi Murad. The novel "War and Peace" was translated in its entirety from French by the Egyptian writer and translator Edward Harrat. Numerous reprints indicate Egyptian readers' great interest in the novel.

Leo Tolstoy's novels "Anna Karenina" and "Resurrection" were filmed in Egypt, but the most popular film was "Nahr al-Hubb" ("River of Love"), which was shot in the 1960s based on the novel "Anna Karenina". Famous Egyptian actors Omar Sharif and Faten Hamama starred in the roles of Vronsky and Anna Karenina. The plot of the novel was adapted to the Egyptian reality: the action takes place at the present time, the characters have Arab names.

According to M.A. Rodionov, in general the ideas of Leo Tolstoy, A.M. Gorky and other Russian writers which penetrated to the Middle East in translations "gave hope that to Arabs the Russian culture is closer than the West European one". Thus, the Egyptian prose writer Taufik al-Hakim (1898-1999) in the autobiographical novel "Bird from the East" (1938) reflects on the fate of the East and Europe, making the following statement through the mouth 
of Russian Ivan: "Europe, like a child walking on the surface of the hidden knowledge which opened the true meaning of human existence to the civilizations of Asia and Africa long ago". Many "Silver Age" writers visited Egypt and made a pilgrimage to the holy places. Among them was famous Russian writer, Nobel Prize winner for literature Ivan Bunin, who visited Alexandria, Cairo, Port Said, Aswan, etc. His vivid impressions of the travels around the country of the pyramids as well as the treatment in the sanatorium in Helwan inspired him to create a number of works which became significant milestones in his work. These are "Delta" - a story about Alexandria, "Light of the Zodiac" - an essay about Cairo, verses "Cairo", "Alexander in Egypt", "Flight into Egypt", etc.

Well-known Russian Egyptologist Vladimir S. Golenishchev, a rich man who had been fond of ancient Egypt since his childhood and knew the ancient Egyptian language, made annual trips to Egypt, during which he amassed a collection of Egyptian antiquities. Subsequently, he went bankrupt and had to sell to the state the collection containing more than 6 thousand exhibits. Before the 1917 revolution, he had been the curator of the collection of Egyptian antiquities in the Hermitage. He did more than 50 translations of ancient Egyptian texts and comments to them into Russian. It is important to note that it was he who founded the Department of Egyptology at Cairo University. The Egyptian Hall of the Pushkin State Museum of Fine Arts in Moscow is almost $100 \%$ filled with his personal collection. He bequeathed his archive to Garneau, the Frenchman who took it to Paris, where it became the foundation of the scientific institute-centre of V.S. Golenishchev.

In 1869, delegations from many European countries arrived in Egypt for the opening of the Suez Canal. Russia sent a steamer; on its board as part of the Russian delegation, there arrived the famous maritime painter Ivan Aivazovsky, who had been commissioned to sketch the opening of the Suez Canal. He was fascinated by the greatness of the desert, the pyramids, the sphinxes, and on his return he painted a number of pictures on Egyptian subjects: "The caravan in an oasis. Egypt" (1871), "Pyramids" (1895), "Scenes from Cairo Life" (1881).

In the era of decadence, at the turn of the $20^{\text {th }}$ century, in Russia there was a new surge of interest in Egypt, which was largely due to the search for a new world view, accompanied by an appeal to mysticism, as we see in the works by V. Solovyov, V. Rozanov, A. Benois. In 1908, there was staged A. Arensky's ballet "Egyptian Nights". In 1916, V. Bryusov published a stylized continuation of

${ }^{8}$ M.A. Rodionov, "Rossiya kak inokulturniy areal v arabskoy traditsii," in Vsmatrivayas drug v druga. Rossiya i arabskiy mir; vzaimnoye vospriyatiye. Sbornik statey (Moscow: Institut vostokovedeniya RAN Publ., 2013): 23-31. 
Pushkin's poem "Egyptian Nights". In late 1909, Balmont visited Egypt and wrote a series of essays, which later became part of the book "The Edge of Osiris" (1914).

\section{Main vectors in the development of bilateral cooperation in the $20^{\text {th }}-21^{\text {th }}$ centuries}

In the early $20^{\text {th }}$ century, it was the October Revolution of 1917 in Russia which had a significant impact on the progressive part of Egyptian society. Although at first the communist movement in Egypt was weak and fragmented, the communist groups united hundreds of people at best, mainly from the progressive intellectuals; in 1922 the Socialist Party of Egypt was recognized as a member of the Comintern (Communist International) and became known as the Communist Party of Egypt ${ }^{9}$.

The socialist ideas, which at that time gained wide popularity in various countries of the world, proved to be not alien to Islamic organizations: many Muslim theologians proclaimed the kinship of the original Islam with socialism; they even preached "Islamic socialism", which had many adherents in the Arab countries, including Egypt ${ }^{10}$.

In the Soviet era, there radically changed the ideological tasks of the art the main goal of which was the glorification of the revolution, its heroes and leaders. The revolution was an event of a worldwide scale, which inevitably brought to the forefront monumentality as a stylistic dominant. This primarily affected the image of Moscow. In these conditions, the relevance of the obelisk and the pyramid was especially evident against the background of the search for a new symbolism different from the forbidden Christian one. The obelisk became one of the main forms of revolutionary monuments (for example, the "Obelisk of Freedom", 1918), which was widely spread due to the simplicity, laconicism and expressiveness of its image. The monument-obelisk in the Alexander Garden, erected originally to the $300^{\text {th }}$ anniversary of the House of Romanovs, was converted into a monument in honour of the heroes of the revolution. It is no coincidence that during the construction of the Lenin Mausoleum, architect A. Shchusev used the theme of the pyramid symbolizing the greatness of the deceased man.

It should be noted that at the end of World War II, in Egypt interest in the USSR was great, and the attitude of the Egyptians to Soviet people was

9 E.M. Primakov, Blizhniy Vostok na stsene i za kulisami (Moscow: Rossiyskaya gazeta Publ., 2006), 71.

${ }^{10}$ Ibid., 16. 
sincerely sympathetic. On May 15, 1944 with the showing of the documentary "Stalingrad" in the Cairo cinema "Opera", there was launched a campaign to raise funds to help the civilian population of the USSR. The whole Egyptian political elite headed by King Farouk were present at the screening ${ }^{11}$

It was during the presidency of Gamal Abdel Nasser that the RussianEgyptian relations experienced an unprecedented heyday. However, as E.M. Primakov notes, when the "Free Officers" came to power in Egypt, at first the attitude towards them in Moscow was rather skeptical. The main evaluation criterion at that time was the distance that separated them from local communists. In Egypt this distance was very significant ${ }^{12}$. After the 1952 revolution, Nasser began to implement socialist-oriented reforms, directing Egypt's foreign policy towards close cooperation with the USSR. During that period (1955-1975), there was unprecedentedly large-scale bilateral cooperation in the military sphere. According to the former Soviet ambassador to Egypt A. Belonogov, in those 20 years the USSR delivered weapons, ammunition and various military equipment to Egypt for more than 5 billion roubles (at that time the rouble rate was higher than the dollar) on favourable terms (50\% of the cost). In that period, about 8000 Egyptian soldiers were trained in the USSR ${ }^{13}$. In Egypt, there were opened representative offices of Aeroflot, Intourist, Vneshtorgbank, Sovexportfilm, International Book, Marine Ministry, Fisheries Ministry, Novosti news agency, which proves the development of the bilateral contacts in a wide variety of spheres. The apogee of that cooperation was the construction of the Aswan High Dam in Egypt with the help of Soviet specialists; the Aswan High Dam is the energy base of the Egyptian economy. After the completion of the construction in honour of the SovietEgyptian friendship, there was erected a 76-meter monument in the shape of a blossoming lotus.

It is obvious that the necessary prerequisite for the development of the national economy of a particular country is the creation of an energy base in it. It was with this that the economic cooperation of the USSR with Egypt was launched. The Aswan hydropower complex became the largest facility, the construction of which was provided with economic and technical assistance ${ }^{14}$.

${ }^{11}$ Afrika vo vtoroy mirovoy voyne (Moscow: Institut Afriki RAN Publ., 2005), 35.

${ }^{12}$ E.M. Primakov, Blizhniy Vostok na stsene i za kulisami (Moscow: Rossiyskaya gazeta Publ., 2006), 71.

${ }^{13}$ A.M. Belonogov, Posol v strane pyramid (Moscow: Institut vostokovedeniya RAN Publ., 2008), 113.

${ }^{14}$ Afrika v sovremennom mire i rossiysko-afrikanskiye otnosheniya (Moscow: Institut Afriki Publ., 2000), 56. 
In addition, the metallurgical plant built with the technical assistance of the USSR in Nag Hammadi still produces 240.000 tons of aluminum per year.

Amidst these changes, in Egyptian literature there started to dominate the socialist trend, taking as its basis the artistic principles of Russian and Western European realistic classical literature of the late $19^{\text {th }}$ and early $20^{\text {th }}$ centuries. It is the analysis of the development of individual and society which began to occupy the central place in literary works. The generation of Egyptian innovative writers proclaimed as their main task the creation of their national literature. Renouncing the attempts to revive the genre forms of the classical medieval literature, but not interrupting the connection with the tradition, the "new realists" of the 1950s were guided by Chekhov's stories and Italian neo-realism. There were created epic novels like "War and Peace" by Leo Tolstoy, completing the formation of a new genre system of Egyptian prose. Under the great influence of F.M. Dostoevsky (along with the works of Sartre, Camus, Hemingway), whose collected works were published in Egypt in the late 1950s, one sees in Egyptian prose not the previous integral vision (rua) of the surrounding world by the author, but the depiction of this world in the individual subjective perception of the characters. Of great popularity were the works by A.M. Gorky, which (in particular, the play "The Lower Depths") in 1956 inspired the Egyptian writer Noaman Ashur to write the play "People who are at the bottom". The play was a great event in the theatrical life of Egypt, laying the foundations of the author theatre. Many researchers noted A.P. Chekhov's great influence on the work of one of the most talented Arab writers of the $20^{\text {th }}$ century, Youssef Idris: for example, his stories "In Assiut", "Not to blame", "After the walk", etc. The common motives of the early stories of the two writers are indeed obvious; however this is not a borrowing and imitation, but a result of the similarity of attitude and understanding of the human personality, which is partly explained by the commonality of the profession and medical practice. Thus, by the middle of the $20^{\text {th }}$ century, the experience of Western European and Russian realistic prose had been assimilated and revised by Egyptian writers, and it became a natural part of their artistic consciousness ${ }^{15}$.

At the same time, in Egypt there was forming the system of musical education, where a significant role was played by Soviet musicians invited to Egypt to work. On the other hand, many Egyptian musicians studied at music educational institutions in the USSR. Along with that, in Russia the Arab music school has been known for a long time to a wide audience, in particular, through the adaptation in the works of Russian composers A.P. Borodin, M.A. Balakirev,

${ }^{15}$ V.N. Kirpichenko, V.V. Safronov, Istoriya egipetskoy literatury 19-20 vekov. Vol. 2 (Moscow: Vostochnaya literature RAN Publ., 2003), 269. 
N.A. Rimsky-Korsakov. As A.Z. Yegorin states, "There is no doubt that the long-standing and established connections of writers and thinkers, artists and poets of Egypt and Russia mutually enriched and still enrich Russian and Arab cultures" 16 .

In the 1950s there were opened specialized scientific institutions the main task of which was "to study history, economy, language and literature of the peoples of Africa", including Egypt, concentrating this "mainly at the Institute of Oriental Studies of the Russian Academy of Sciences" 17 .

Subsequently, the political situation played a decisive role in the development of the bilateral relations: during the presidency of Anwar Sadat, who reoriented to the West, the spheres of the development of Soviet-Egyptian relations considerably narrowed, in particular, at most facilities (98) the cooperation ended; Soviet specialists continued to work only at 13 facilities, where they mainly engaged in modernization (Helwan metallurgical plant, cement plant in Assiut, at-Tabin refractory plant, etc.). The Soviet propaganda mainly portrayed Egypt in the negative light, emphasizing the American presence. The Egyptian propaganda responded in the same way, criticizing the socialist ideas and the Soviet leadership. It was only with pragmatic politician Hosni Mubarak's coming to power that there began gradual normalization of the relations and their return to the previous level. According to A.M. Rodriguez, Hosni Mubarak actually continued Sadat's course, mitigating his excesses in both economic and political life. From 1987, there began the period of improving relations of Egypt with the Arab countries, as well as with the USSR, while Egypt continued to get full support from the Western powers, primarily the USA ${ }^{18}$.

It should be noted that in the early 1990s the contacts between Russian and Egyptian Muslims sharply intensified, which was due to the fact that foreign contacts of Russian Muslims went out of state control after the collapse of the USSR and their connections with religious non-governmental organizations of Islamic countries, including Egypt, were intensified with the aim of reviving the Muslim religion in places of its traditional distribution in the territory of Russia. Their cooperation with the Egyptian al-Azhar University which is considered the largest centre for the training of Muslim theologians and ministers of the cult developed especially actively. The main direction of this cooperation were the preparation of clergymen for Russian Muslim institutions and organizations at al-

${ }^{16}$ A.Z. Egorin, Egipet v pamyati russkoy (Moscow: Institut vostokovedeniya RAN Publ., 2015), 51-52.

${ }^{17}$ Arhiv RAN, f. 2, op. 6a, d. 124, 11. 4-5.

${ }^{18}$ A.M. Rodriguez, Istoriya stran Azii I Afriki v noveyshee vremya (Moscow: Prospekt Publ., 2006), 392. 
Azhar University and the invitation of Egyptian teachers to Russian educational institutions for the same purpose.

This rapidly expanding cooperation has sparked a surge of interest of Egyptian researchers in the Muslims of Russia. Some Egyptian researchers dedicated their works to studying the features of Islam in Russia, its distribution areas, the number of Russian Muslims ${ }^{19}$.

But in the opinion of a number of experts, along with positive results there has been a disturbing trend as some students of al-Azhar were influenced by the ideology of religious revival taught by some preachers ${ }^{20}$.

A great achievement in the development of the bilateral relations in the scientific sphere was Russia's getting the right to excavate in Egypt. After the completion of the archaeological works under the guidance of B.B. Piotrovsky in the early 1960s, Russia for a long time had no opportunity to excavate in Egypt, although scientific expeditions from other countries continued to actively work there, as the legacy of the ancient Egyptian civilization is so great that for searches and studies of artifacts Egypt is forced to seek help from foreign Egyptologists. Thanks to the support of famous Egyptian archaeologist Dr. Zahi Hawass, who in 2002 was appointed Director General of the Supreme Archaeological Council of Egypt, in the permanent committee on Egyptian antiquities, after many years Russia began to excavate in Giza again.

It is tourism which has had a special place in the bilateral relations until recently. As the foreign trade activity of Egypt is characterized by a huge chronic deficit, tourism occupies a special place in the structure of the economy. Before the severing of tourist connections with Egypt for the reasons related to the security of Russian citizens, Egypt had been annually visited by about 2 million Russian tourists (14\% of foreign tourists) who spent about 2 billion dollars in the resorts of Hurghada and Sharm al-Sheikh ${ }^{21}$.

It should be noted that it was President Putin's first visit to Egypt in April 2005 which was the first impetus to the development of the bilateral relations; in particular, there began cooperation in the areas of business and investment (for example, the Egyptian side invested 250 million dollars in the production of TU-204 aircraft), Egyptian aviation company "Egypt Air" and the tourist

${ }^{19}$ Masri Djamil Abdulla Muhammad, The modern Islamic world and its problems (AlRiyad: asl-Abikan Publ., 2000), 498-525.

${ }^{20}$ A.B. Podtserob, Rossiyskiy islam i zarubezhniye RNPO (www.iimes.ru rus|stat|2008| 12-03-08).

${ }^{21}$ S. Zhdanov, Arabskiye strany v mirovoy economike (Moscow: MGIMO-Universitet Press, 2015), 139. 
company "Egypt Travel" opened their agencies in Russia, there were organized numerous exhibitions and festivals, tours of art groups; in 2006 in Cairo there was founded the Egyptian-Russian University. In addition, there were developing the contacts between religious figures of the two countries who actively participated in the international public forum "Dialogue of Civilizations"22.

At the present stage, it is the bilateral relations in the sphere of education which are developing very actively. In both countries, the leading educational institutions train specialists in the field of Arabic studies, Egyptology, and Russian studies. In Russia these are Lomonosov Moscow State University, St. Petersburg University, MGIMO, the RUDN University, Kazan University, etc.; in Egypt - Cairo University, Ain Shams University. A milestone in this direction was the creation of Egyptian-Russian University in the suburb of Cairo in 2006 under the leadership of Dr. Sherif Helmi, the first university in the Arab world having partnerships with seven leading Russian universities, including the RUDN University. Within the framework of these agreements, there are carried out academic exchanges, exchange of scientific publications; there are summer and winter schools for students and university lecturers.

It is necessary to say that Egyptian researchers throughout the history of the relationship between the two countries indicate a significant difference in Russian oriental studies from the Western ones. They consider that Russian oriental studies have never been based on the idea of enmity between the West and Islamic East or religious fanaticism, but its incentive was to know the East. Thus, the well-known Egyptian scholar Ashraf Muhammad Abdel Rahman Minis notes that Russian travelers and orientalists differ in friendliness and sympathy for the Arabs and an objective analysis of events in contrast to Western orientalists who treat Egyptians with a sense of superiority, and their works shows a prejudiced attitude toward the described phenomena and events. This approach makes Russians closer to Egyptians and more respected by them than Western orientalists. ${ }^{23}$

\section{Conclusions}

Thus, one can say that the bilateral relations in terms of intercivilizational interaction were developing gradually. They got the first powerful impetus to their development during the rise of the Russian Empire and the consolidation

${ }^{22}$ A.M. Vasilyev, Ot Lenina do Putina. Rossiya na Blizhnem i Srednem Vostoke (Moscow: Tsentrpoligraf, 2018), 463.

${ }^{23}$ Ashraf Mohammed Abdel Rahman, Russian Travellers and Orientalists and their Vision of Egypt of the Times of Muhammad Ali (Cairo: Adab Publ., 2015), 101-102. 
of its positions in the international arena, namely during the reign of Peter the Great and Catherine the Great, which was associated with Russia's active foreign policy. Subsequently, these relations were expanded and cemented, obtaining a powerful basis for the development through the establishment of Oriental studies, Egyptology, and Russian studies, embracing new spheres.

The political situation and economic factors had decisive influence on the dynamics of the development of Russian-Egyptian relations. At the same time, historical experience shows that real cooperation between peoples is possible only under conditions of mutual respect for national interests, constructive dialogue, the desire to learn each other and to enrich themselves with each other's experience, rather than by imposing their values.

Due to its geographical location, demographic potential, its key role in the region, Egypt has traditionally been the sphere of Russia's interests. Currently, Russia is actively seeking to return to the region.

With a solid historical base, the bilateral relations significantly expanded in the first decade of the 21 st century due to the agreements on cooperation in the economic sphere, scientific and technical aspects, including the field of high technologies, nuclear energy, communications, medicine, pharmaceuticals, space area. The cultural cooperation has gained a new impetus. At the same time, it should be noted that at the moment the bilateral relations are experiencing stagnation due to a number of crisis phenomena taking place in Egypt, primarily in the security sphere.

Submitted: 2 May 2018

(C) Galina Lukyanova, Elena Paymakova, 2018

Рукопись поступила: 2 мая 2018 г.

\section{References}

Ad-Dali Mohammed Sabri. Contemporary Russia in the Egyptian historical texts. Cairo: Supreme Council for Culture Publ., 2008 (in Arabic).

Ashraf Mohammed Abdel Rahman. Russian Travellers and Orientalists and their Vision of Egypt of the Times of Muhammad Ali. Cairo: Adab Publ., 2015 (in Arabic).

Afrika vo vtoroy mirovoy voyne [Africa in World war II]. Moscow: Institut Afriki RAN Publ., 2005 (in Russian).

Afrika v sovremennom mire i rossiysko-afrikanskiye otnosheniya [Africa in the modern world and Russian-African relations]. Moscow: Institut Afriki Publ., 2000 (in Russian).

Belonogov, A.M. Posol v strane pyramid [Ambassador to the land of the pyramids]. Moscow: Institut vostokovedeniya RAN Publ., 2008 (in Russian). 
Belyakov, V.V. Yegipet vdol i poperyok. Istoritcheskiy gid [Egypt up and down. Historical guide]. Moscow: Vetche Publ., 2005 (in Russian).

Vasilyev, A.M. Yegipet i yegiptyane [Egypt and Egyptians]. Moscow: Vostochnaya Literatura Publ., 2008 (in Russian).

Vasilyev, A.V. Ot Lenina do Putina. Rossiya na Blizhnem i Srednem Vostoke [From Lenin to Putin. Russia in the Middle East]. Moscow: Tsentrpoligraf Publ., 2018 (in Russian).

Gerasimov, O.G. Vostotchnyye uzory [Oriental patterns]. Moscow: Nauka Publ., 1993 (in Russian).

Zhdanov, S.V. Arabskiye strany v mirovoy economike [Arab countries in the world economy]. Moscow: MGIMO-Universitet Press, 2015 (in Russian).

Egorin, A.Z. Egipet v pamyati russkoy [Egypt in memory of Russian]. Moscow: Institut vostokovedeniya RAN Publ., 2015 (in Russian).

Ivanov, N.A. Trudy po istorii islamskogo mira [Works on the history of the Islamic world]. Moscow: Vostochnaya Literatura Publ., 2008 (in Russian).

Kirpichenko, V.N., Safronov, V.N. Istoriya egipetskoy literatury 19-20 vekov [History of Egyptian literature of the $19^{\text {th }}-20^{\text {th }}$ centuries]. Moscow: Vostochnaya literature RAN Publ., 2003 (in Russian).

Masri, Djamil Abdulla Muhammad The modern Islamic world and its problems, al-Riyad: al-Abikan Publ., 2000 (in Arabic).

Norov, A.S. Puteshestviye po Yegiptu i Nubii v 1834-1835 gg [The journey through Egypt and Nubia in 1834-1835]. Sankt-Petersburg Publ., 1840 (in Russian).

Podtserob, A.B. Rossiyskiy islam i zarubezhniye RNPO [Russian Islam and foreign religious non-govenmental organizations]. www.iimes.ru rus|stat|2008|12-03-08 (in Russian).

Primakov, E.M. Mir posle 11 sentyabrya [The world after September 11]. Moscow: Mysl Publ., 2002 (in Russian).

- Blizhniy Vostok na stsene $i$ za kulisami [East on stage and behind the scenes]. Moscow: Rossiyskaya gazeta Publ., 2006 (in Russian).

Rodionov, M.A. "Rossiya kak inokulturniy areal v arabskoy traditsii.” [Russia as an ethnocultural area in the Arab tradition] In Smilyanskaya, I.M. ed. Vsmatrivayas drug v druga. Rossiya i arabskiy mir; vzaimnoye vospriyatiye. Sbornik statey [Looking at each other. Russia and the Arab world; mutual perception. Collected papers], 23-34. Moscow: Institut vostokovedeniya RAN Publ., 2013 (in Russian).

Rodriguez, A.M. Istoriya stran Azii I Afriki v noveyshee vremya [History of Asia and Africa in modern times]. Moscow: Prospekt Publ., 2006 (in Russian)..

\section{Archives}

Arhiv RAN [Archive of Russian Academy of Scinse], f. 2, op. 6a, d. 124. 


\title{
Российско-египетские отношения в аспекте межцивилизационного взаимодействия
}

\author{
Г.О. Лукьянова ${ }^{\text {a }}$ Е.А. Паймакова ${ }^{a}$ \\ аРоссийский университет дружбы народов \\ 117198 Россия, г. Москва, ул. Миклухо-Маклая, 6 \\ lukianova_go@rudn.university
}

\begin{abstract}
Аннотация: Статья посвящена развитию российско-египетских отношений в аспекте межцивилизационного диалога. В ней анализируется динамика развития отношений в различные исторические эпохи, а также факторы, оказавшие решающее влияние на характер двустороннего взаимодействия. Глобализационные процессы, в условиях которых живет современный мир, расшатывают все сложившиеся на протяжении многих веков модели национальной и культурной идентификации и ставят под угрозу само существование народов, наций и культур в их нынешнем виде. Это вызывает закономерное сопротивление, стремление к сохранению национальной идентичности. В сложившихся условиях особую значимость приобретает межнациональный культурный диалог. Данная статья посвящена рассмотрению подобного диалога российской и египетской культур, где особую роль играли и продолжают играть политические, экономические, культурные, научные и духовные связи. Идеи Л.Н. Толстого, А.М. Горького и других деятелей русской культуры, проникшие в Египет, получили здесь особую популярность, оказав значительное воздействие не только на умы прогрессивной египетской интеллигенции, но и на развитие египетской литературы. Хотя Россия долгое время рассматривалась арабскими и, в частности, египетскими историками и общественными деятелями как часть Запада, после октябрьской революции 1917 года в России Советское государство стало восприниматься как особая сила, противостоящая материалистическому Западу. Начиная с 50-х гг. XX в. большое значение для Египта имеет военно-техническое, экономическое и культурное сотрудничество с СССР, впоследствии с Россией. В то же время в статье анализируется влияние египетской культуры на духовную и интеллектуальную жизнь России.
\end{abstract}

Ключевые слова: российско-египетские отношения, межцивилизационное взаимодействие, культуры Востока и Запада, политическая конъюнктура

Для цитирования: Лукъянова Г.О., Паймакова Е.А. Российско-египетские отношения в аспекте межцивилизационного взаимодействия // Вестник Российского университета дружбы народов. Серия: История России. 2018. Том 17. № 3. С. 718-734. DOI: 10.22363/2312-8674-2018-17-3-718-734 